\title{
9. Polycentricity and Citizenship in Environmental Governance
}

\author{
Graham R. Marshall and Anas Malik ${ }^{1}$ \\ Draft June 7, 2018
}

\begin{abstract}
This chapter is concerned with relationships between governance arrangements and environmental citizenship, and with the challenges of establishing and sustaining governance conducive to this citizenship. The significance of this concern is illustrated by Australian experiences with governance arrangements seeking to promote citizenship among rural landholders in natural resources conservation. In considering this concern we take our lead from a line of thinking about polycentric governance that was developed by Vincent Ostrom, who drew in turn from de Tocqueville's early 19th century analysis of the American democratic 'experiment'. Ostrom identified 'the way people think and relate to one another' (pertaining to the meta-constitutional level of analysis in the Institutional Analysis and Development framework) as fundamentally significant for meeting the challenges of achieving polycentric governance capable of promoting citizenship, and also the citizenship required to sustain polycentric governance. Key insights drawn by Ostrom regarding the meta-constitutional conditions required for forms of polycentric governance conducive to citizenship are reviewed in this chapter to suggest areas for continuing research into the viability of self-governing polycentric orders. Progress in empirical investigation of relationships between polycentric governance and environmental citizenship is reviewed. One relationship of this kind is illustrated with reference to attempts at policy reform towards environmental watering in Australia's Murray-Darling Basin.
\end{abstract}

\subsection{Introduction}

Citizenship in conserving the environment and natural resources has become a topic of increasing interest to policy makers and scholars as the capacities of governments to meet the escalating conservation challenges of the Anthropocene become increasingly stretched (Chen et al. 2009). In much of the world since the late nineteenth century, the role of citizens in democratic societies has been understood conventionally through the paradigm of 'political modernism'. This paradigm viewed centralised modes of governance (wherein all significant public policy decisions are made by central governments and then implemented through a bureaucratic chain of command) as ideal, and the appropriate involvement of citizens in these processes as therefore limited to voting periodically in elections for political representatives (Ostrom 1991).

The interest in citizenship as a means of helping to solve contemporary conservation problems stems from critiques that political modernism is ill-fitted to the complexity of these problems (Marshall 2010) and recognition of a need to augment centralised efforts to solve

\footnotetext{
${ }^{1}$ The authors' intellectual contributions to this chapter were of equal significance. The chapter benefited from comments by Andreas Thiel, William Blomquist, Dustin Garrick, and others. This material has been published in revised form in Governing Complexity: Analyzing and Applying Polycentricity edited by Andreas Thiel, William A. Blomquist, and Dustin E. Garrick, Cambridge University Press. pp 197-218 DOI:

https://doi.org/10.1017/9781108325721.010 The present version is free to view and download for private research and study only. Not for re-distribution or re-use. (C) Cambridge University Press.
} 
them by strengthening the motivation (civic virtue) and means (civic capacity) for citizens to willingly 'co-produce' solutions (Ostrom 1990). The 'environmental citizenship' (Dobson 2007) or 'ecological citizenship' (Wolf, Brown, and Conway 2009) invoked in such discussions accords with Heater's (2004 p. 182) argument that "[h]e who has no sense of a civic bond with his fellows or of some responsibility for civic welfare is not a true citizen whatever his legal status", and with V. Ostrom's (1991 p. 256) emphasis on the importance for sustaining democracy of "the willingness of people to cope with problematical situations instead of presuming that someone else has responsibility for them".

This interest has led to research efforts across multiple disciplines (e.g., Dobson and Bell 2005) seeking to better understand the antecedents of environmental citizenship so that steps might be taken to strengthen, or at least not weaken, this phenomenon in particular conservation settings. Our concern in this chapter is with that portion of those efforts concerned with relationships between governance arrangements and environmental citizenship, and with the challenges of establishing and sustaining governance conducive to this citizenship.

\subsubsection{Investing in environmental citizenship: an illustrative case}

The significance of this concern, and the difficulty of these challenges, can be illustrated by an ambitious 'experiment' in Australia with governance arrangements seeking to promote citizenship (typically referred to in this context as 'self-help' or 'self-reliance') among rural landholders in natural resources conservation that has been underway since the 1980s (Curtis et al. 2014). This citizenship can manifest in multiple ways within this context, including: voluntary adoption of conservation practices; exerting peer pressure on neighbours to adopt such practices; supporting establishment of a local natural resource management (NRM) group; serving on the committee of such a group; coordinating the activities of such a group with those of neighbouring groups; contributing skills, labour and/or equipment to group activities (e.g., controlling weeds in adjoining public lands); and sharing knowledge of local issues with governments (Marshall 2011).

The Australian Government sought to catalyse this process in the 1990s by investing public funds in supporting formation and facilitation of 'landcare' and related groups (Curtis et al. 2014). These groups were established predominantly at the neighbourhood level, typically with membership of a few dozen farming families. About one-third of Australian farming families became involved in more than 6,000 landcare-type groups (Campbell 2016). The essence of the Landcare initiative has been described as "landholders working in their own local social group to solve their own local land conservation problems in their own way" (Poussard 1992 p. 233) and "promoting sustainable environmental and natural resources management through voluntary collective action at a neighbourhood or district level" (Campbell 2016).

In the early 2000s the Australian Government introduced what became known as the 'regional delivery model', under which its funding of on-ground natural resource management (NRM) activities would be channelled through new organisations established for 56 NRM regions it newly delineated across the nation. Choosing to establish this governance at the regional level was justified by claims that this level was best suited not only for integrating local NRM actions by landcare and other groups, but also for engaging the community in NRM (Council of Australian Governments 2000). 
Community engagement was nevertheless soon identified as a major challenge for the regional NRM organisations. Most of these organisations saw their roles less as building on the Landcare initiative's successes in promoting local self-reliance than using public funds more strategically and professionally to externally motivate landholders to act on NRM issues determined from the top down as national priorities (Campbell 2016). The large sizes of the regions also made community engagement difficult, with many local NRM groups viewing the regional NRM organisations as remote from the communities with which they actually identified (Regional Implementation Working Group of the NRM Ministerial Council 2005).

Landcare groups are now struggling across much of Australia. Some of this decline in environmental citizenship has been attributed to those responsible for developing the regional delivery model "fail[ing] to articulate how the regional framework should relate to voluntarism and, as a result, undermin[ing] it. ... The tendency for the regional NRM policy reform to displace and undermine rather than augment community Landcare was a grave error" (Campbell 2016).

\section{Vignette: $\quad$ Polycentricity and citizenship in environmental watering - the case of Australia's Murray-Darling Basin}

Efforts at policy reform to achieve environmentally sustainable water use in the MurrayDarling Basin (MDB) commenced in the early 1990s as a cooperative-federalist initiative of the Commonwealth and state/territory governments. Progress in implementing the agreed water policy reforms was slow, however. In the depths of a prolonged drought, when Australia's most important river system was claimed to be in crisis, the Commonwealth intervened through the Water Act 2007 to take control of the reform agenda (Garrick 2015).

The Murray-Darling Basin Authority (MDBA) was established under the Water Act 2007 to develop and implement a Basin Plan. Legislated in 2012, this Plan provides for a reduction in surface water use of about 20 per cent from pre-existing levels. The Commonwealth Environmental Water Holder $(\mathrm{CEWH})$ was also appointed under this Act to manage the Commonwealth's holdings of 'environmental water' entitlements acquired through a AUD $\$ 13$ billion water recovery program.

The Basin Plan has been described as "one of Australia's most controversial water policies ever implemented" (Wheeler et al., 2017 p. 253). The preceding Guide to the Basin Plan brought to a head mounting criticism of what had become widely characterised as a centralised, technocentric approach to developing the Plan. The strength of the irrigation lobby's negative reaction to the Guide led the Commonwealth to disavow "a key principle under which the [MDBA] had operated, namely that environmental sustainability was a binding requirement for the Plan" (Quiggin 2011 p. 53).

Byron (2011 p. 389) observed that the centralised approach to developing the Basin Plan had left local people with "little commitment to the strategy. Without their commitment, the strategy will lack the necessary cooperation at the grassroots level. ... [T] he key [to turning this around] is to start with the knowledge and energy of the people on the ground ..." Similarly, Horne et al. (2014 p. 129) identified subsidiarity - "devolving the maximum work and decision-making to the lowest level possible, while still retaining the capacity for Basinwide environmental watering outcomes" - as vital for strengthening citizenship in MDB 
environmental water management. They argued that the increased autonomy granted to local organisations through subsidiarity would enable these organisations to gain greater trust from their constituents. Nesting these local organisations, and indeed organisations at higher levels, within the larger governance system in ways that preserve their essential autonomy would, moreover, enable "trust at the local level to filter up so that trust extends from local communities up to Basin-wide agencies" (ibid. p. 129).

O'Donnell et al. (2017) observed that the CEWH's early focus on efficiency and effectiveness in environmental water management had not been sufficient to gain trust from local communities, and noted that this entity had sought more recently to build this trust by nesting local arrangements within its broader strategy for managing environmental water. In 2012, for instance, the CEWH formalised a partnership agreement with a non-government organisation (NGO), Nature Foundation South Australia, under which it would make available 10 gigalitres of water each year to use in wetlands located in that state. This NGO became accountable to the CEWH for managing the delivery of this water, including through engaging local communities in deciding where, when and how the water should be used.

The current incumbent in the CEWH position has identified the value of such partnerships in gaining trust and cooperation from private landholders and other community members. He observed that these partnerships "sort of grow organically, if they're working, and so far they are. ... I just see these things, with appropriate limitations imposed by legislative responsibilities and resourcing implications, growing in spread and value. ... My understanding is evolving with my experience of it; so I'm seeing it already being more powerful than I thought it could be. ... I think the system that will work is one that's built around a realistic understanding of who's best suited to do what" (David Papps interviewed in Marshall 2017 pp. 199, 200, 209).

\subsubsection{Focus of this chapter}

In pursuing our concern with relationships between governance and citizenship in the environmental policy domain, and the challenges of establishing and sustaining governance conducive to this citizenship, we take our lead from a line of thinking about polycentric governance that was developed at length by Vincent Ostrom but often overlooked by other analysts of this form of governance. This line of thinking drew from insights drawn by Alexis de Tocqueville (2003) in the early $19^{\text {th }}$ century from his analysis of the American democratic experiment. Tocqueville warned that the social basis of democratic order could be undermined by erosion of the citizenship that had enable this experiment to take root and flourish. Ostrom's (1997) final book-length work was subtitled A Response to Tocqueville's Challenge. To the extent that the scope of scholarship within the Bloomington school of political economy is adequately captured by the name of the academic group from which this school took its lead - the Workshop in Political Theory and Policy Analysis - Vincent's work exemplified the 'political theory' tradition within this scholarship.

Ostrom (1991 p. 8) identified "the way people think and relate to one another" as fundamentally significant for achieving and sustaining polycentric governance supportive of citizenship and vice versa. He viewed polycentric governance as both contributing to and depending on the self-governing capacities of citizens. His concern with how citizens think and relate to one another pertains to what is understood in the Bloomington school's 'policy analysis' tradition of scholarship, and particularly through its Institutional Analysis and 
Development (IAD) framework, as the meta-constitutional level of analysis. This rarelyanalysed level of the IAD framework (Ostrom 2005b) "encompasses long-lasting and often subtle constraints on the forms of constitutional, collective, or operational choice processes that are considered legitimate within an existing culture" (McGinnis 2011 p. 173).

Key insights drawn from the American democratic experiment by Vincent Ostrom (1991) regarding the meta-constitutional conditions required for establishing and sustaining forms of polycentric governance conducive to promoting citizenship are considered in section 2 of this chapter, as they suggest areas for continuing research into the viability of self-governing polycentric orders. One way to think about this is in terms of Douglass North's (2005 p. 1) suggestion that social change is driven by at least three components: beliefs, the stock of knowledge, and institutions. Our beliefs about reality, imperfect as they necessarily are, form part of the stock of knowledge. Vincent Ostrom's emphasis on metaconstitutional conditions touches on both beliefs and institutions. The metaconstitutional level raises questions of intersubjectivity that extend beyond the academic discipline of psychology into such areas as ontology, epistemology, metaphysics, hermeneutic keys, and starting points generally. Examining these issues often requires an interdisciplinary openness, which can sometimes be difficult for social scientists. Yet they are important in the Bloomington school perspective as articulated by Vincent Ostrom in particular, and are areas for ongoing research.

Recognising that the metaconstitutional conditions upon which American democracy was founded had weakened considerably under the pervasive influence of political modernism, Ostrom subsequently proposed that alternatives to this paradigm should be founded on the theory of collective action in public goods provision: "When the central problem in public administration is viewed as the provision of public goods and services, alternative forms of organization may be available for the performance of these functions apart from the extension and perfection of bureaucratic structures" (Ostrom 2008 p. 16). This proposal was acted on in the 'policy analysis' tradition of the Bloomington school scholarship; most notably by Elinor Ostrom who in her book Governing the Commons: The Evolution of Institutions for Collective Action (Ostrom 1990) laid out a far-reaching agenda for empirical research into how institutions of state, common and individual property interact with one another and other attributes of action situations to influence provision of common-pool resources. In section 3, we document the progress achieved in implementing this agenda in respect of understanding relationships between polycentric governance and citizenship in the environmental policy domain. The chapter concludes in section 4 with suggestions for further research.

\subsection{Insights from the 'American democratic experiment'}

The meta-constitutional foundations for citizenship conducive to polycentric governance can be found in diverse settings around the world. These meta-constitutional orientations are not exclusive or unique to the United States. The American experience includes a historical lineage of self-governing townships of Anglo-American settlers, with a relative equality of social condition, and a departure from an aristocratic social context. The prominent role of civic engagement in shaping the rules governing local communities attracted the attention of Alexis de Tocqueville, who also argued that the American case was part of a geographically and historically broader millennium-long trend toward social equality and democracy. Investigations of the American experience can help inform understandings of potentials and vulnerabilities of self-governing polycentric orders in the United States and elsewhere. 
For Vincent Ostrom (1991 p. 5) the concept of democracy “implies that people govern". He concluded from his analysis of the American democratic experiment that a particular constitutional order - polycentric governance - is of basic importance for understanding how the citizenship required for a self-governing society might be achieved and maintained. $\mathrm{He}$ understood polycentric governance as generalising the concept of federalism, which had come to be defined narrowly as a governance arrangement where authority is exercised concurrently by a national and state (or provincial) governments. For him " $[\mathrm{t}]$ he crucial issue is that the concept of federalism enables people to break out of the conceptual trap inherent in a theory of sovereignty that presumes there must exist some single center of supreme authority that rules over society" (ibid. p. 8).

Ostrom (1991) asserted that people necessarily proceed from metaphysical assumptions even unacknowledged or implicit ones - in providing meaningful starting points from which to work together in attempting to solve their own problems. He observed that a shared understanding of these metaphysical assumptions is crucial to these attempts, and that such a shared understanding - particularly in respect of the value of federalism grounded in covenantal practices - in the case of the American democratic experiment was made possible by the religious beliefs of the Pilgrims of New England who sowed the seeds of this experiment.

He noted that that the word federalism is derived from the Latin term for covenant, and that the Pilgrims adhered to federal theology which was at the time "a covenantal theology ... developed by some Protestants to conceive a system of church governance ..." (Ostrom 1991 p. 9). Covenant can be defined as "a foundational affirmation of open-ended mutual obligation that is difficult to break even if it is not consistently reciprocated" (Malik 2017). A "proper covenantal order" was defined by Ostrom (1991 pp. 61-62) as "one in which a covenanting people chooses to act in a way that is consistent with a transcendent order, 'which it is that men call God', and with their idea of one another as a people who are faithful to their covenant with God and respectful of God's creation". He observed that in the Mayflower Compact the Pilgrims effectively covenanted themselves to a federal (or polycentric) system of governance. It was federal in the original linguistic sense, and also federal/polycentric in the broader sense as the local self-governing units interacted with each other and formed multiple layers of relationships.

Ostrom emphasized the potential of 'Golden Rule' covenants to provide a normative anchor for a polycentric constitutional order. The Golden Rule refers to wanting for others what one wants for oneself, and is grounded in a metaphysical supposition that all people are created equal. Versions of the Golden Rule have a prominent position in the Abrahamic traditions, inter-religious collaboration initiatives, and ethical teachings from other contexts (Malik 2013, 2017, 2018). Ostrom (1991 p. 54) argued that conceiving the Golden Rule as a method of normative inquiry "opens the way to a community of understanding, to the development of just laws, and to drawing upon the resources of others to enhance our own understanding of ourselves and the world in which we live. It is these elements as they are bound together in covenantal relationships that give meaning to American federalism as a public philosophy - a metaphysics for citizenship in self-governing societies" (Ostrom 1991 p. 54). The selfgoverning habits that provide the building blocks of a polycentric order rest on civic commitments to devise and revise rules which are appropriate for particular contexts yet consider and take into account the interests and perspectives of others. 
Since the Golden Rule "is surprisingly devoid of moral content" (ibid. p. 54), such a method of normative inquiry by any group of individuals will lead to a covenantal order consistent with their shared moral precepts. Hence it may, at least in initial rounds of its application, lead members of a particular group within society (e.g., upstream irrigators) to covenant (e.g., in respect of their permissible levels of water extraction) in ways considered to be morally deficient by other groups (e.g., downstream irrigators or environmentalists). Applied at a higher (e.g., river basin) level, however, the method offers the prospect of a mutually-agreed normative basis for resolving such conflicts. In pursuing this prospect, Ostrom (1991 p. 54) argued, "it is possible for human beings to strive for an understanding of universals applicable to nature as God's creation and, as a result, to achieve some rudimentary appreciation of how human beings might best relate themselves to one another and to God (that which is eternal)". This raises the ongoing research question of what set of intersubjective understandings beyond the Golden Rule promote conflict resolution processes and entrepreneurial efforts to identify and build upon complementarities to promote collectively desirable outcomes.

Eventual extension of the notion of citizenship to the national level in America was made possible, Ostrom (1991) argued, by meta-constitutional conditions conducive to growing federalism grounded in covenantal practices incrementally upwards from the local level. The English colonial mode in the American colonies happened to be favourable for the emergence of self-governing townships. Thus, the early emigrants "continually exercised the rights of sovereignty ... as if their allegiance was due only to God", and there was a freedom from political prejudices which enabled them to experiment freely with political principles, laws and other institutions (Tocqueville, 1956: 44). Tocqueville regarded this early history as pivotal to democracy because "town meetings are to liberty what primary schools are to science; they bring it within people's reach, they teach men how to use and enjoy it" (in Ostrom 1991 p. 213). He noted that this practical education in citizenship was complemented by the high value placed by the early emigrants on public education.

These early local-level experiences served as a foundation upon which successive generations of Americans would come to build in extending their citizenship as far as enabling them ultimately to constitute a self-governing society at the national level. Vincent Ostrom (1991) observed accordingly how:

[T] he federal system of 1787 emerged from some 167 years of experience in fashioning civil bodies politic by covenanting and combining together to form local units of government and colonial charters. With this cultural heritage, people were able to undertake the American Revolution, the formulation of state constitutions, the organisation of Continental Congresses, the Articles of Confederation, and the Constitution of the United States. People looked to one another in constituting associations that exercised the prerogatives of government.

Vincent Ostrom (1991) observed that this meta-constitutional heritage of the American people, which had enabled them to come to govern themselves polycentrically as a nation, found itself undermined from the late $19^{\text {th }}$ century onwards by the advent of political modernism. In place of the shared community of understanding that had underpinned a bottom-up covenantal method of citizens governing themselves polycentrically, political modernism sought to substitute the understanding that citizens are governed more effectively the more that governance is centralised towards a single decision-making centre. This paradigm steadily gained influence not only in the USA but internationally, reaching its 
zenith in the 1960s and 1970s when considerable faith existed in the capacity of strong, national governments to solve all public problems through top-down interventions (Ostrom 2000, Marshall 2005).

Far from being unique to the American context, the meta-constitutional orientations comparable to Golden Rule covenants are found in numerous contexts. Daniel Elazar (1998) described notions of covenant in the Jewish context, and Malik (2018) has argued that the Islamic tradition includes covenantal thinking as well as other elements conducive to polycentric order. Vincent Ostrom (1997) argued that covenant-like understandings existed in Confucian, Islamic, and other contexts. Indeed, it is arguable that versions of Golden Rule covenant-like orientations can be found in many ethical systems in the world. The American experience provides a cautionary and still-evolving tale about the vulnerabilities of polycentric governance to strategies of dominance or control which, coupled with loss of the habits of self-governance, lead to increasingly monocentric decision-making.

\subsection{Collective action and civic virtue}

The premise of political modernism that citizens are incapable of self-organising effective solutions to the problems they share was given intellectual credence in the mid- $20^{\text {th }}$ century by non-cooperative game theory (particularly the Prisoner's Dilemma game) and the conventional theory of collective action. In his seminal contribution to this theory, Mancur Olson (1965 p. 2) concluded that "unless the number of individuals in a group is quite small, or unless there is coercion or some other special device to make individuals act in their common interest, rational, self-interested individuals will not act to achieve their common or group interests".

This inability of individuals to act collectively (except in small groups) in solving their shared problems is posited in this theory to follow from an irresistible temptation to 'free ride' on others' efforts which prevents them from volunteering their own contributions. On the basis of non-cooperative game theory, moreover, it became conventionally accepted among scholars that individuals faced with collective action problems cannot use communication as a way of making credible commitments to one another to resist temptations to free ride. All such communication, including of the covenantal kind, thus became viewed as mere 'cheap talk' (Ostrom 1998). Elinor Ostrom (2010 p. 248) observed upon being co-awarded the Nobel Memorial Prize for Economic Sciences how this conventional theory of collective action corroborated the political-modernist assumption "that the momentum for change [towards realising collective action] must come from outside the situation rather than from the selfreflection and creativity of those within a situation to restructure their own patterns of interaction".

The influence of the conventional theory of collective action on shared community understanding of the role of citizens in their own governance was amplified by publication of Garrett Hardin's (1968) 'The tragedy of the commons,' which made similar predictions regarding the capacity of individuals to solve their problems of collective action (or more specifically the subset of these known as 'commons dilemmas'). Hardin predicted that users of any common-pool resource will in the absence of external intervention be trapped in overusing and ultimately destroying the resource. This article captured the attention of policy makers and scholars worldwide, and spurred an immense theoretical and empirical research 
effort of particular relevance to environmental citizenship given the common-pool characteristics of many environmental and natural resource systems.

\subsubsection{Developments in a behavioural theory of collective action}

The Bloomington school research effort started with case studies that identified numerous contemporary examples across many nations where tragedies of the commons had been avoided through self-organized collective action. However, "[n]o single case study was conclusive; each could be dismissed as an anomaly" (Poteete, Janssen, and Ostrom 2010 p. 32). Adoption of a standard framework for analysis - based on the IAD Framework - made it easier to compare cases and identify patterns across them. Moreover, experiments performed in the laboratory and field in numerous cultural settings around the world have confirmed that in controlled replicable situations self-organised solutions to commons dilemmas can emerge more often than predicted by the conventional theory of collective action.

Of particular relevance to Vincent Ostrom's identification of covenantal practices as foundational to the American people's achievements in establishing a self-governing society, experimental studies have consistently demonstrated the important role of face-to-face communication in enabling self-organized solutions to commons dilemmas - even where promises made as a result of this communication cannot be enforced (Ostrom 2010).

Malik (2017) argued that the moral psychology of covenant distinguishes the Bloomington school from other schools of public choice such as the Austrian approach. A question for ongoing research concerns the nature of covenant or functionally similar understandings in different cultural settings. Vincent Ostrom suggested several possibilities in the Jewish, Islamic, and Confucian contexts (V. Ostrom, 1997), while Malik (2018) has described covenant-like understandings and other religio-cultural practices consonant with polycentricity in the Islamic tradition. Shivakumar (2005) suggests that covenant-like understandings can be found in most or all cultures. A related research question is the degree to which covenant-like understandings are specific to polycentric governance rather than political orders more generally.

From this cumulative research effort spurred by the 'tragedy of the commons' prediction, a behavioural theory of collective action is emerging which "views humans as adaptive creatures who attempt to do well given the constraints and opportunities of the situations in which they find themselves (or which they seek out). Humans learn norms, heuristics, and full analytical strategies from one another, from feedback from the world, and from their capacity to engage in self-reflection and imagine a differently structured world" (Poteete, Janssen, and Ostrom 2010 p. 222).

This behavioural theory recognises that human motivations in responding to collective action problems are more diverse than the rational egoism assumed as universally applicable in the conventional theory. Whereas rational egoists contribute to collective action only when motivated to do so by externally-implemented incentives, the behavioural theory of collective action has been developed from experimental evidence that contributions by at least some individuals are motivated by internalised social norms; e.g., relating to reciprocity, trustworthiness and fairness. Individuals with such internalised motivations may respond to collective action problems as conditional cooperators (contributing to joint efforts depending on their assessments that other beneficiaries can be trusted to reciprocate), and thereby 
become motivated to initiate efforts in solving these problems that increasing numbers of others may eventually come to reciprocate as a result of mutually-reinforcing feedbacks between cooperation level, trust, reputation for trustworthiness, and reciprocity (E. Ostrom 2000, E. Ostrom 1998).

A cautionary note is appropriate here: reciprocity and collective action are not universally desirable from the point of view of society. Reciprocity among a tight circle of similar individuals can, for instance, lead to discrimination against people of a different religion or ethnicity. And "[i]t is everyone else's interest that some [collective action problems] are not resolved, such as those involved in monopolies and cartel formation, and those that countervene basic moral standards and legal relationships, and those that restrict the opportunities for an open society and expanding economy" (E. Ostrom 1998 pp. 17-18, original emphasis). Polycentric arrangements are vulnerable to strategies of dominance. An important research question in this context is whether the Golden Rule needs to be accompanied by a norm of non-dominance to promote well-functioning polycentric governance.

The mutually-reinforcing feedbacks between trust in others, the investments others make in trustworthy reputations, and the propensities to follow reciprocity norms are at the core of the behavioural theory of collective action. Whether these feedbacks serve in a particular setting to strengthen or weaken cooperation in contributing to collective action depends on a diverse array of structural variables. Ostrom (1998) called for research into the effects of different structural variables on the likelihood of people organising successfully for collective action, and highlighted in particular a need for research into how institutions enhance or detract from the building of mutual trust, reciprocity and reputations. Of particular relevance to this call, Frey et al. (2001 p. 604) observed:

Civic virtue (a particular manifestation of intrinsic motivation) is bolstered if the public laws convey the notion that citizens are to be trusted. Such trust is reflected in extensive rights and participation possibilities.... The basic notion enshrined in the constitution that citizens are on average, and in general, reasonable human beings thus generates a crowding-in effect of civic virtue. In contrast, a constitution implying a fundamental distrust of its citizens, and seeking to discipline them, tends to crowd out civic virtue and undermines the support which citizens are prepared to give towards the basic law.

We turn now to considering the potential for polycentric constitutional orders, predicated on trust that citizens are capable of governing themselves, to crowd-in the civic virtue required (along with civic capacity) for this capability to be realised.

\subsubsection{Civic virtue: insights from self-determination theory}

This observation was informed by a body of research by behavioural economists in the tradition of Motivation Crowding Theory (MCT) (Frey 2012, Frey 1997). MCT took its lead from early work by social psychologists in developing Self-Determination Theory (SDT) (Deci 1971, 1975). According to SDT, individuals are most likely to optimise satisfaction of their psychological needs, and thus experience wellbeing, when they feel autonomous. Ryan et al. (2011 pp. 59-60) observed that "when people act autonomously, rather than being controlled or amotivated, they act with a sense of choice, are more mindful, think flexibly, 
and express their values and interests". Intentional actions are regarded as autonomous in this tradition only to the extent that they are experienced as fully volitional.

SDT distinguishes types of motivation based on their relative autonomy (Ryan and Deci 2011). The most general distinction is between intrinsic and extrinsic motivation. Intrinsic motivation arises from the inherent satisfaction an individual experiences from an action; that is, from enjoying an activity for its own sake. Although intrinsic motivation is an important impetus for action in many circumstances, it is not normally the most important determinant of behaviour: much of human behaviour is motivated, initially at least, by factors external to the self. SDT distinguishes between four main types of external (extrinsic) motivation that vary in the degree to which behavioural regulations are internalised. Two of these motivation types involve a high degree of internalisation and volition, so SDT scholars have grouped them with intrinsic motivation into a more general motivational category called autonomous motivation (ibid.). Civic virtue can be understood as a manifestation of this type of motivation.

Important insights into the civic virtue dimension of environmental citizenship are offered by SDT. This theory offers a psychological explanation of how behavioural changes that arise initially from externally-induced motivations can become permanently internalised as socially-endorsed values, identities and institutions become more fully integrated to the self. It proposes that the potential for internalisation of behaviour changes that were motivated at first externally can be realised to the extent that the values, identities and institutions are transmitted to individuals in a manner that they perceive supports their autonomy rather than seeks to control, them. Both proximal and distal contextual influences on whether the manner on which transmission occurs is perceived as autonomy-supportive or controlling are recognised as relevant by SDT (Ryan and Deci 2011). Proximal contextual influences include parents and peers who interact regularly with an individual, while distal influences include the mass media and governments (Pelletier, Baxter, and Huta 2011).

E. Ostrom (2000 p. 13) referred to findings from both MCT and SDT in observing that "much of contemporary policy analysis and the policies adopted in many modern democracies crowd out citizenship", while E. Ostrom (2005a pp. 254-255) did likewise in arguing that "instead of relying on the state as the central, top-down substitute for all public problem solving, it is necessary to design complex, polycentric orders that involve both public governance mechanisms and private market and community institutions that complement each other.... Reliance primarily on national governments crowds out public and private problem solving at regional and local levels ...".

However, the advantages of polycentric governance for developing and sustaining the civic virtue dimension of citizenship were not clearly articulated on the basis of these theories. The advantages of this kind of governance for citizenship were more clearly identified in terms of its civic capacity dimension; i.e., "the capacity of citizens to experiment with diverse ways of coping with multiple problems and to learn from this experimentation over time" (ibid. $p$. 270). Such advantages for civic capacity are illustrated by the enhanced opportunities for practical education in covenanting as a basis for self-governance that Vincent Ostrom (1991) identified as having flowed from evolution of the polycentric structure of the American democratic experiment from the bottom up. More recent illustrations of the advantages of polycentric governance for growing and sustaining civic capacity include Blomquist's (1992) study of groundwater governance in southern California, and Acheson's (2003) analysis of lobster industry governance in Maine. While suggestive, these cases do not provide 
conclusive evidence of the advantages of polycentric governance for growing and sustaining civic capacity due to lack of comparison with counter-factual (non-polycentric) cases. Future research designed to fill this gap would make a significant contribution to the literature on this form of governance.

\subsection{Subsidiarity, community-based governance, and civic virtue}

Marshall et al. (2017) argued within an SDT framework that the advantages of polycentric governance in respect of the civic virtue, or autonomous motivation, dimension of environmental citizenship can be expected to accrue to the extent that this governance is organised in accordance with the principle of subsidiarity. This principle proposes that governance be structured such that decision-making in respect of any matter be assigned to the level closest to the individual where it can be exercised competently. Higher-levels of governance are understood accordingly as subsidiary to lower-level ones (and ultimately to the individual), not the reverse as has conventionally come to be presumed (Marshall and Stafford Smith 2010).

Governance of this kind is polycentric, but the definition of polycentric governance does not require it to be consistent with the subsidiarity principle. While this definition requires that all decision-making centres encompassed by this constitutional order be formally independent of one another (Ostrom, Tiebout, and Warren 1961), formal independence is no guarantee of de facto decision-making autonomy (Marshall 2015, Carlisle and Gruby 2017), and the level of such autonomy experienced by individuals and their proximate groupings under polycentric governance may be less than that entailed by the subsidiarity principle. V. Ostrom (1991 p. 270) was concerned, for instance, that despite the polycentric (or federal) constitutional order of American democracy there had been an erosion of the shared community understanding which had enabled this order to become established, which had led in turn to a drift towards "democratic despotism" as rule-making in practice became increasingly relegated to central authorities. He observed: "Federalism is a sham if covenants become mere words on paper" (ibid. p. 272).

\subsubsection{Community-based governance}

Polycentric governance arrangements organised in accordance with the subsidiarity principle have been described as community-based (Marshall 2009, Marshall et al. 2016). A community-based approach to polycentric governance is consistent with Andersson et al. (2008) observing that the polycentric approach to institutional analysis assumes that the selfgoverning capabilities of citizens and their associations should be the foundation for higherlevel governance arrangements. The characterisation of community-based governance as polycentric governance structured in accordance with the subsidiarity principle is consistent with Berkes (2005 p. 34) using the term community-based governance as "shorthand for governance that starts from the ground up but deals with cross-scale interactions", and with Berkes' (2007 p. 15193) description of such governance in the conservation context as "extend[ing] beyond communities to include institutional linkages and multiple levels of organization that impact and shape institutions at the local level". Berkes $(2007,2017)$ was concerned to remedy the common misapprehension that community-based governance is limited to community-level governance. The concept of community-based polycentric governance is implicit in Tocqueville's (2003 p. 30) depiction of the township as the starting 
unit of political organization in the establishment of American democracy, with "the township ... organized before the county, the county before the State, and State before the Union ${ }^{2} \%$.

The significance for community-based environmental governance of E. Ostrom's (1990) eighth design principle for robust governance of common-pool resources was highlighted by Marshall $(2005,2008)$. This 'nesting principle' requires inter alia that governance of such resources be "organised in multiple layers of nested enterprises" (ibid. p. 90). Communitybased environmental governance can accordingly be characterised as the "result of larger, more inclusive organizational units emerging from, and then 'nesting' - in the sense of complementing rather than absorbing or sidelining - smaller, more exclusive units that manage to self-organize sooner. Smaller organizations thus become a part of a more inclusive system without giving up their essential autonomy" (Marshall 2005 p. 47).

Marshall $(2009,2008,2005)$ proposed that the value of nesting lower-level governance structures, rather than supplanting or sidelining them, follows from the 'vertical' problems of collective action that arise as 'higher' levels of governance are introduced. Adding a higherlevel structure was argued to augment efforts by lower-level actors to self-organise remedies to their 'horizontal' problems of collective action only to the extent that they trust the structure to reciprocate their own efforts; otherwise these actors would free-ride on higherlevel efforts to help solve these problems (thus cancelling out the effect of higher-level efforts) or oppose these efforts (Marshall 2009). Retaining governance structures that actors have self-organised, and minimising restrictions on the autonomy of these structures, was seen as helping with the vertical problems of collective action since actors "can be expected to place greater trust in units they create for themselves and in which they maintain collective-choice property rights" (Marshall 2008 p. 77). The potential for subsidiarity and the nesting principle to contribute towards realising the environmental-citizenship-building aspirations of Australia's regional delivery model for NRM were recognised by Campbell (2016) when observing that the model had "failed to capture the potential synergies inherent in what could have been one of the world's best examples of nested, multi-level systems of community-based governance of natural resources" (see also Ryan et al. 2010).

Self-organised structures that become nested in the process of developing more inclusive arrangements for environmental governance have been likened to the "mediating structures" of civil society that the sociologists Berger et al. (1977 p. 3) identified as important for making members of modern society feel "more 'at home' in society, and the political order ... more meaningful" (Reeve, Marshall, and Musgrave 2002, Marshall 2002). Mediating structures are seen as fulfilling this role by retaining a capacity to present distinct 'private' and 'public' faces. They are claimed to protect individuals and their proximate groupings from the alienation of modern life, while strengthening the legitimacy of governments and other higher-level governance structures by helping them to connect with local perceptions, values and norms. They are thus seen as making it more possible to establish trust, reciprocity and cooperation up and down a governance arrangement by breaking into smaller steps what may otherwise be alienating social distances (Marshall 2005). This effect might be understood through an SDT lens as arising from inclusion of mediating structures within governance arrangements making it more likely that the arrangements will be perceived as supportive of individuals' autonomy.

\footnotetext{
${ }^{2}$ The 'Union' refers here to the confederal and federal arrangements that underlie the United States of America.
} 


\subsubsection{Empirical findings}

Empirical evidence in respect of the foregoing claims made in the literature regarding the relationship between community-based polycentric governance and civic virtue (understood here as autonomous motivation to reciprocate higher-level contributions to collective action) remains scant, however. Cardenas, Stranlund and Willis (2000) found from field experiments in rural Colombia that external control in solving local commons dilemmas led to inferior outcomes when (as is typically the case) the control is only modestly enforced, compared with allowing local community members to self-organise solutions to these dilemmas. The main reason for the inferior performance of external control was found to be its crowding out of group-regarding motivations associated with civic virtue.

Marshall (2009) found from multiple regression of survey data from 821 farmers operating within three of the 56 regions serviced by Australia's regional delivery model for NRM (see section 1.2) that farmers were more likely to practise reciprocity in their dealings with the model the more localised their engagement with it. Reciprocity in this context involved an intention to adopt the on-farm conservation practices promoted to them under the model to a greater extent when they trusted it to support them in their adoption efforts. In two of the three regions, community engagement with the model occurred at the sub-regional level, whereas in the third region it occurred only at the regional level. It was proposed on the basis of this evidence that "subregional bodies have an advantage over regional bodies in motivating [reciprocity] from farmers because the former are better positioned to engage them sufficiently to turn around norms of free-riding or opposition entrenched by earlier paternalistic approaches to agri-environmental conservation" (Marshall 2009 p. 1507). Referring subsequently to this research, Marshall (2011 p. 122) observed that it offers:

... some evidence ... for the proposition that the ability of a community-based approach to engage farmers in relationships of reciprocity ... tends to increase the more that responsibilities under the approach are devolved towards the local level. However, further evidence is needed for this proposition to be evaluated with reasonable confidence.

Other empirical evidence regarding the relationship between community-based polycentric governance and civic virtue comes from a study by Marshall et al. (2017) that was designed to test hypotheses deduced from SDT. The study sought to determine whether communitybased, compared with government-centred, governance would increase citizens' support in the form of donations to a trust fund designed to support climate change adaptation. A sample of 548 adults from the Australian state of New South Wales (NSW) was randomly assigned to view one of two governance scenarios - government-centred and community-based. Each participant had been informed they would receive a supplementary payment of AUD\$10 for participating in the study.

After briefly describing climate change threats, both scenarios advised that a trust fund had recently been established to increase the funds available for investing in the participant's region's capacities to adapt to climate change impacts.

In the government-centred scenario, the trust "was established, and will be administered, by the regional office of the NSW Government agency responsible for helping communities adapt to climate change" (ibid. p. 5). In the community-based scenario, the trust was 
established at "a meeting between community representatives of voluntary community groups ... working on natural resource management issues in your region. The idea was further developed through a collaborative partnership between these community representatives and the regional office of the NSW Government agency responsible for helping communities adapt to climate change. The partners agreed that final decisions on how to invest the funds donated to the trust would be made by a committee comprised entirely of representatives from your regional community" (ibid. p. 5). Hence, the content of the two scenarios was identical other than the description of the relative roles of government and community in establishing the trust fund and deciding how funds held in the trust would be invested.

Following the administration of the experimental treatment, participants answered questions regarding the degree to which governance arrangements for the trust fund described in the scenario were perceived as supportive of their community's autonomy, and about their personal motivations for supporting such a trust. Finally, participants were asked how much of their supplementary payment they would be willing to donate to the trust fund, noting that they could keep what they chose not to donate. Participants were informed following the study that the scenarios were fictitious and they could keep all of their supplementary payment regardless of what they had agreed to donate.

Path analysis revealed that the community-based scenario yielded significantly higher levels of perceived autonomy support among the study's participants. High levels of perceived autonomy support predicted higher levels of autonomous motivation (or civic virtue) and lower levels of amotivation. This motivational pattern predicted, in turn, significantly greater willingness to donate to the trust fund. The conclusion from these findings was that "community-based governance may be an effective strategy for reducing crowding-out effects, and thereby strengthening citizenship, in institutional initiatives to facilitate climate change adaptation" (ibid. p. 7). Noting that the regional level was chosen as the focus of both governance scenarios since it is a level at which government-centred and community-based governance arrangements have both operated in Australia, including under the NRM regional delivery model, it was suggested that future research could examine whether the influence of community-based governance on civic virtue (and thereby citizenship) depends on the spatial level at which individuals are able to engage with this governance.

\subsection{Conclusion and suggestions for further research}

Elinor Ostrom (2010 p. 665) closed her Nobel prize acceptance address by arguing that "a core goal of public policy should be to facilitate the development of institutions that bring out the best in humans. We need to ask how polycentric institutions can help or hinder the innovativeness, learning, adapting, trustworthiness, levels of cooperation of participants, and the achievement of more effective, equitable, and sustainable outcomes at multiple scales ..." In this chapter we have offered some answers to this question, particularly in respect of the capacities and motivations of citizens to contribute towards governance of collective action in conserving nature and natural resources. In doing so we have looked towards scholarship from both the 'political theory' and 'policy analysis' traditions of the Bloomington school of political economy.

We find that polycentric governance does have potential to foster and sustain these capacities and motivations comprising environmental citizenship. We conclude also that the prospects for realising this potential in any given context depend on how the governance is actually 
established and operated, which depends in turn on the metaconstitutional conditions pertaining to that context. The literature we have reviewed suggests that the potential for polycentric governance to strengthen and sustain environmental citizenship will be realised to the extent that this governance is established and operated in accordance with the subsidiarity principle and E. Ostrom's (1990) nesting principle; i.e., as a system of community-based governance. It suggests also that covenantal practices akin to those identified by V. Ostrom (1991) as central to the incremental development of American democracy may be important more generally for establishing and running such community-based systems of polycentric governance.

The evidence base from which these propositions have been derived remains patchy, however. Further empirical studies of the relationship between community-based governance and environmental citizenship are required to corroborate (or not) the few such evaluations completed to date. Although experimental evidence of the important role of face-to-face communication in enabling self-organised solutions to commons dilemmas is consistent with the identification of covenantal practices as integral to the evolution of American democracy, further research is needed to increase our understanding of the significance of such practices in diverse cultural and institutional settings, including within and between higher (including governmental and supranational) levels of governance.

Our understanding of the metaconstitutional conditions conducive to community-based governance (and its underpinning covenantal practices) in settings of environmental management, and of how to establish and sustain those conditions, is particularly thin. While the corrosive effects of political modernism on these conditions are clear, it is far less clear how these effects might be reversed in contemporary settings such that the prospects of establishing community-based environmental governance, and in turn the environmental citizenship on which it depends, are made more favourable. There is a crucial role here for research that helps us to better understand the obstacles and opportunities in achieving such transitions in diverse settings. Specific research questions here include: (i) are covenants (or functionally-equivalent understandings) universal or culturally specific? (ii) is a norm of nondominance jointly sufficient with covenant for well-functioning polycentric governance? (iii) can entrepreneurial efforts to revive covenantal understandings improve the performance of polycentric governance in tackling environmental sustainability challenges? and (iv) beyond the empiricist concepts we use in positivist social science, what ways of knowing are appropriate for analysis of metaconstitutional concepts relating to metaphysics?

\section{References}

Acheson, J.M. 2003. Capturing the Commons: Devising Institutions to Manage the Maine Lobster Industry. Hanover, NH: University Press of New England.

Andersson, K., and E. Ostrom. 2008. "Analyzing decentralized resource regimes from a polycentric perspective." Policy Sciences 41:71-93.

Berger, P.L., and R.J. Neuhaus. 1977. To Empower People: The Role of Mediating Structures in Public Policy. Washington, D.C.: American Enterprise Institute.

Berkes, F. 2005. "Why keep a community-based focus in times of global interactions?" Topics in Arctic Social Sciences 5 (33-43).

Berkes, F. 2007. "Community-based conservation in a globalized world." Proceedings of the National Academy of Sciences of the USA 104 (39):15188-15193. 
Berkes, F. 2017. "Environmental governance for the Anthropocene? Social-ecological systems, resilience and collaborative learning." Sustainability 9:1232. doi: $10.3390 / \mathrm{su} 9071232$.

Blomquist, William. 1992. Dividing the Waters: Governing Groundwater in Southern California. San Francisco: ICS.

Byron, N. 2011. "What can the Murray-Darling Basin Plan achieve? Will it be enough?" In Basin Futures: Water Reform in the Murray-Darling Basin, edited by D. Connell and R.Q. Grafton, 385-398. Canberra: ANU E Press.

Campbell, A. 2016. "Two steps forward, one step back: The ongoing failure to capture synergies in natural resource management (Australia)." In Transformational Change in Environmental and Natural Resource Management: Guidelines for Policy Excellence, edited by M.D. Young and C. Esau, 80-94. Abingdon, U.K.: Routledge.

Cardenas, J.C., J.K. Stranlund, and C. Willis. 2000. "Local environmental control and institutional crowding out." World Development 28 (10):1719-1733.

Carlisle, K.M., and R.L.B. Gruby. 2017. "Polycentric systems of governance: A theoretical model for the commons." Policy Studies Journal https://doi.org/10.1111/psj.12212.

Chen, X., F. Lupi, G. He, and J. Liu. 2009. "Linking social norms to efficient conservation investment in payments for ecosystem services." Proceedings of the National Academy of Sciences 106 (28):11812-11817.

Council of Australian Governments. 2000. Our vital resource: A National Action Plan for Salinity and Water Quality. Canberra.

Curtis, A., H. Ross, G.R. Marshall, C. Baldwin, J. Cavaye, C. Freeman, A. Carr, and G.J. Syme. 2014. "The great experiment with devolved NRM governance: Lessons from community engagement in Australia and New Zealand since the 1980s." Australasian Journal of Environmental Management 21 (2):175-199.

Deci, E.L. 1971. "Effects of externally mediated rewards on intrinsic motivation." Journal of Personality and Social Psychology 18 (1):105-115.

Deci, E.L. 1975. Intrinsic Motivation. New York: Plenum Press.

Dobson, A. 2007. "Environmental citizenship: Towards sustainable development." Sustainable Development 15 (4):276-285.

Dobson, A., and D. Bell, eds. 2005. Environmental Citizenship. Cambridge MA: MIT Press.

Elazar, D. 1998. Covenant and Civil Society: The Constitutional Matrix of Modern Democracy. New Brunswick, NJ: Transaction Publishers.

Frey, B. 2012. "Crowding out and crowding in of intrinsic preferences." In Reflexive Governance for Global Public Goods, edited by E. Brousseau, T. Dedeurwaerdere and B. Siebenhüner, 75-83. Cambridge, USA: MIT Press.

Frey, B.S. 1997. Not Just for the Money: An Economic Theory of Personal Motivation. Brookfield, USA: Edward Elgar.

Frey, B.S., and R. Jegen. 2001. "Motivation crowding theory: A survey of empirical evidence." Journal of Economic Surveys 15:589-611.

Garrick, D.E. 2015. Water Allocation in Rivers under Pressure: Water Trading, Transaction Costs and Transboundary Governance in the Western US and Australia. Cheltenham: Edward Elgar Publishing.

Hardin, G. 1968. "The tragedy of the commons." Science 162 (December 13):1243-1248.

Heater, D.B. 2004. Citizenship: The Civic Ideal in World History, Politics and Education. Manchester: Manchester University Press.

Horne, A., and E. O'Donnell. 2014. "Decision making roles and responsibility for environmental water in the Murray-Darling Basin." Australian Journal of Water Resources 18 (2):118-132. 
Malik, A. 2013. "Reconciliation between Muslims and Christians: Collective action, norm entrepreneurship, and "A Common Word Between Us"." Journal of Religious Ethics 41 (3):457-473.

Malik, A. 2017. "Polycentricity and cultural diversity." In Political Theory, Policy Analysis and Institutional Creativity: Extending the Work of the Bloomington School, edited by F. Sabetti and D. Castiglione. Lanham, MD: Lexington.

Malik, A. 2018. Polycentricity, Islam, and Development: Potentials and Challenges in Pakistan. Lanham, MD: Lexington Books.

Marshall, G.R. 2002. "Institutionalising cost sharing for catchment management: Lessons from land and water management planning in Australia." Water, Science and Technology 45 (11):101-111.

Marshall, G.R. 2005. Economics for Collaborative Environmental Management: Renegotiating the Commons. London: Earthscan.

Marshall, G.R. 2008. "Nesting, subsidiarity, and community-based environmental governance beyond the local level." International Journal of the Commons 2 (1):7597.

Marshall, G.R. 2009. "Polycentricity, reciprocity, and farmer adoption of conservation practices under community-based governance." Ecological Economics 68 (5):15071520.

Marshall, G.R. 2010. "Governance for a surprising world." In Resilience and Transformation: Preparing Australia for Uncertain Futures, edited by S. Cork, 49-57. Melbourne: CSIRO Publishing.

Marshall, G.R. 2011. "What 'community' means for farmer adoption of conservation practices." In Changing Land Management: Adoption of New Practices by Rural Landholders, edited by D.J. Pannell and F.M. Vanclay, 107-127. Melbourne: CSIRO Publishing.

Marshall, G.R. 2015. "Polycentricity, subsidiarity and adaptive efficiency." A paper presented to the International Workshop on Polycentricity, Ostrom Workshop in Political Theory and Policy Analysis, Indiana University, Bloomington, Indiana, USA, 14-17 December 2015.

Marshall, G.R. 2017. Cost-effective environmental water for NSW wetlands and rivers. Final report to the NSW Environmental Trust. Armidale: University of New England.

Marshall, G.R., M.J. Coleman, B.M. Sindel, I.J. Reeve, and P.J. Berney. 2016. "Collective action in invasive species control, and prospects for community-based governance: The case of serrated tussock (Nassella trichotoma) in New South Wales, Australia." Land Use Policy 56:100-111.

Marshall, G.R., D.W. Hine, and M.J. East. 2017. "Can community-based governance strengthen citizenship in support of climate change adaptation? Testing insights from Self-Determination Theory." Environmental Science and Policy 72:1-9.

Marshall, G.R., and D.M. Stafford Smith. 2010. "Natural resources governance for the drylands of the Murray-Darling Basin." The Rangeland Journal 32 (3):267-282.

McGinnis, M.D. 2011. "An introduction to IAD and the language of the Ostrom Workshop: A simple guide to a complex framework." Policy Studies Journal 39 (1):169-183.

North, D.C. 2005. Understanding the Process of Institutional Change. Princeton, New Jersey: Princeton University Press.

O'Donnell, E., and D. Garrick. 2017. "Defining success: A multi-criteria approach to guide evaluation and investment." In Water For the Environment edited by A. Horne, M. Stewardson, A. Webb, B. Richter and M. Acreman, 625-645. Amsterdam: Elsevier.

Olson, Mancur. 1965. The Logic of Collective Action. Cambridge: Harvard University Press. 
Ostrom, E. 1990. Governing the Commons: The Evolution of Institutions for Collective Action. Cambridge: Cambridge University Press.

Ostrom, E. 1998. "A behavioral approach to the rational choice theory of collective action." American Political Science Review 92 (1):1-22.

Ostrom, E. 2000. "Crowding out citizenship." Scandinavian Political Studies 23 (1):3-15.

Ostrom, E. 2005a. "Policies that crowd out reciprocity and collective action." In Moral Sentiments and Material Interests: The Foundations of Cooperation in Economic Life, edited by H. Gintis, S. Bowles, R. Boyd and E. Fehr, 253-275. Cambridge, MA: MIT Press.

Ostrom, E. 2005b. Understanding Institutional Diversity. Princeton: Princeton University Press.

Ostrom, E. 2010. "Beyond markets and states: Polycentric governance of complex economic systems." American Economic Review 100 (3):641-672.

Ostrom, V. 1991. The Meaning of American Federalism: Constituting a Self-Governing Society. San Francisco: Institute for Contemporary Studies Press.

Ostrom, V. 1997. The Meaning of Democracy and the Vulnerability of Democracies. A Response to Tocqueville's Challenge. Ann Arbor: The University of Michigan Press.

Ostrom, V. 2008. The Intellectual Crisis in American Public Administration. 3rd ed. Tuscalosa, USA: University of Arizona Press.

Ostrom, V., C.M. Tiebout, and R. Warren. 1961. "The organization of government in metropolitan areas: A theoretical inquiry." American Political Science Review 55:831-842.

Pelletier, L.G., D. Baxter, and V. Huta. 2011. "Personal autonomy and environmental sustainability." In Human Autonomy in Cross-Cultural Contexts: Perspectives on the Psychology of Agency, Freedom and Well-Being, edited by V.I. Chirkov, R.M. Ryan and K.M. Sheldon, 257-277. Dordrecht: Springer.

Poteete, A.R., M.A. Janssen, and E. Ostrom. 2010. Working Together: Collective Action, the Commons, and Multiple Methods in Practice. Princeton: Princeton University Press.

Poussard, H. 1992. "Community Landcare to test government policies and programs." Proceedings of the 7th International Soil Conservation Organisation Conference, Sydney, 27-30 September.

Quiggin, J. 2011. "Why the Guide to the Proposed Basin Plan failed, and what can be done to fix it." In Water Policy Reform: Lessons in Sustainability from the Murray-Darling Basin, edited by J. Quiggin, T. Mallawaarachchi and S. Chambers, 49-62. Cheltenham, UK: Edward Elgar.

Reeve, I., G. R. Marshall, and W. Musgrave. 2002. Resource governance and integrated catchment management. Armidale: Institute for Rural Futures.

Regional Implementation Working Group of the NRM Ministerial Council. 2005. Regional delivery of natural resource management - Moving forward. Canberra http://www.nrm.gov.au/publications/index.html\#books: NRM Ministerial Council.

Ryan, R.M., and E.L. Deci. 2011. "A self-determination theory perspective on social, institutional, cultural, and economic supports for autonomy and their importance for well-being." In Human Autonomy in Cross-Cultural Contexts: Perspectives on the Psychology of Agency, Freedom and Well-Being, edited by V.I. Chirkov, R.M. Ryan and K.M. Sheldon, 45-64. Dordrecht: Springer.

Ryan, S., K. Broderick, Y. Sneddon, and K. Andrews. 2010. Australia's NRM governance system: Foundations and principles for meeting future challenges. Canberra:

Australian Regional NRM Chairs. Online: http://nrmregionsaustralia.com.au/wpcontent/uploads/2013/12/NRM-Governance-in-Australia.pdf (accessed 10 September 2017). 
Shivakumar, S. 2005. The Constitution of Development: Crafting Capabilities for SelfGovernance. New York: Palgrave Macmillan.

Tocqueville, A. de. 2003. Democracy in America. Washington, D.C.: Regnery Publishing. Wolf, J., K. Brown, and K. Conway. 2009. "Ecological citizenship and climate change:

Perceptions and practice." Environmental Politics 18 (4):503-521. 